\title{
The plasminogen activation system in periodontal tissue (Review)
}

\author{
MARZENA WYGANOWSKA-ŚWIĄTKOWSKA ${ }^{1}$, ANNA SURDACKA ${ }^{1}$, \\ EWA SKRZYPCZAK-JANKUN ${ }^{4}$ and JERZY JANKUN ${ }^{2-4}$
}

\author{
${ }^{1}$ Department of Conservative Dentistry and Periodontology, Poznan University of Medical Sciences, \\ Poznań 60-820, Poland; ${ }^{2}$ Protein Research Chair, Department of Biochemistry, College of Sciences, King Saud University, \\ Riyadh 11451, Kingdom of Saudi Arabia; ${ }^{3}$ Department of Clinical Nutrition, Medical University of Gdańsk, \\ Gdańsk 80-211, Poland; ${ }^{4}$ Urology Research Center, Department of Urology, College of Medicine, \\ University of Toledo, Toledo, OH 43614, USA
}

Received December 17, 2013; Accepted January 28, 2014

DOI: $10.3892 /$ ijmm.2014.1653

\begin{abstract}
The plasminogen activation system (PAS) plays an essential role in tissue proteolysis in physiological and pathological processes. Periodontitis is a chronic infection associated with increased proteolysis driven by plasminogen activation. In this comprehensive review, we summarise the effects of PAS in wound healing, tissue remodelling, inflammation, bacterial infection, and in the initiation and progression of periodontal disease. Specifically, we discuss the role of plasminogen activators (PAs), including urokinase PA (uPA), tissue-type PA (tPA), PA inhibitor type 1 (PAI-1) and 2 (PAI-2) and activated plasminogen in periodontal tissue, where their concentrations can reach much higher values than those found in other parts of the body. We also discuss whether PA deficiencies can have effects on periodontal tissue. We conclude that in periodontal disease, PAS is unbalanced and equalizing its function can improve the clinical periodontal tissue condition.
\end{abstract}

\section{Contents}

1. Introduction

2. Plasminogen activation system in periodontal disease

3. Wound healing

4. Inflammation

5. Microbial infection

6. Plasminogen activation system deficiencies

Correspondence to: Dr Marzena Wyganowska-Świątkowska, Department of Conservative Dentistry and Periodontology, Poznań University of Medical Sciences, Poznań 60-820, Poland

E-mail: marzena.wyganowska@periona.pl

Professor Jerzy Jankun, Urology Research Center, Department of Urology, College of Medicine, University of Toledo, Toledo, OH 43614, USA

E-mail: jerzy.jankun@utoledo.edu

Key words: periodontal disease, inflammation, bleeding, plasminogen activation system
7. Inhibitors

8. Conclusion

\section{Introduction}

The plasminogen activation system (PAS) is a complex enzymatic cascade, where individual components activate or deactivate the final product of that cascade, plasmin. The process of plasminogen transformation into plasmin is initiated by two activators, the urokinase plasminogen activator (uPA) and the tissue-type PA (tPA), which are controlled by PA inhibitor type 1 (PAI-1) and type 2 (PAI-2) and the protein, nexin $(1,2)$. Moreover, urokinase can be present as a free enzyme or can bind to the cell surface by the uPA receptor (uPAR) $(3,4)$.

The physiological significance of the urokinase plasminogen system results from the widespread role of plasmin in physiology and pathology. Plasmin degrades fibrin into soluble peptides and is responsible for the elimination of its excess from the circulatory system and tissues. In addition, it actively hydrolyses numerous proteins, including, laminin and type IV collagen, which are the basic structural elements of the extracellular matrix and vascular basement membrane. Their decomposition takes place both in consequence of the direct action of plasmin and indirectly, due to its activating the cascade of matrix metalloproteinase (MMP) precursors, such as MMP-1 (collagenase precursor), MMP-3 (stromelysin precursor) and MMP-9 (gelatinase B precursor) (5). Under in vivo conditions, plasminogen and plasmin are present in the blood circulation and in the matrix on the cellular surface (6). The activation of plasminogen by tPA is mainly related to processes of the dissolving of fibrin in the vascular injury region. On the other hand, uPA acts in the extracellular space, activating plasminogen, initiating a proteolytic cascade reaction there. The intensive spot concentration of urokinase on the cell surface leads to the increased formation of plasmin and focused proteolytic activity, enabling cell migration (6-9). Moreover, uPA/uPAR and extracellular matrix vitronectin or integrins can adhere cells to the extracellular matrix. Since the uPA/UPAR complex can be internalized, degraded by 
endocytosis in cooperation with the transmembrane lowdensity lipoprotein-related-receptor (LPR) under certain conditions, it creates some areas free of these complexes. Thus, the newly synthetized uPA/uPAR complex will 'seek' vitronectin and integrins intensifying cell motility. These proadhesive pro-motility urokinase properties are not related to its proteolytic activity $(6,10)$. By interaction with the specific receptor located on the cellular surface, urokinase acquires unique chemokine-like characteristics and regulates migration and the related processes of changes in cell shape, adhesion, chemotaxis and invasion of the extracellular matrix (8).

The overexpression of PAs (tPA and uPA) has been found in numerous human diseases (1). PAI-1 is the main physiological inhibitor of uPA and IPA, belonging to the serpin superfamily (serine proteinase inhibitors), and it is produced as a single chain glycoprotein, composed of 402 amino acids with a molecular weight of $45 \mathrm{kDa}$ (11). Its essential function in the organism is to regulate PA activity and, consequently, the formation of plasmin (Fig. 1). Thus, PAI-1 is an important element of systemic homeostasis, which influences the physiological equilibrium of coagulation and fibrinolytic systems under in vivo conditions. Its abnormal elevated expression is observed in a number of pathogenic processes, including atherosclerosis, coronary artery disease, sepsis, multiple sclerosis, pulmonary and renal fibrosis, obesity and insulin resistance, as well as neoplastic disease $(2,12-14)$.

PAI-1 is a highly specific inhibitor of tPA and UPA; however, it is not stable and converts itself into the latent form, with a half life ranging between $t_{1 / 2}=1-2 \mathrm{~h}$, which is unable to interact with target molecules. This presents an obstacle in using wild-type PAI-1 as a hemostatic drug $(20,21)$. Therefore, PAI-1 mutants have been produced in the past which delay or prevent its conversion into the latent form (Fig. 2), extending its half-life to approximately $\mathrm{t}_{1 / 2}=6-170 \mathrm{~h}(16-18)$. The most stable is the VLHL PAI-1 mutant with an engineered disulphide bridge (Cys197-Cys355); without disrupting the molecular structure it prolongs its half-life to approximately $\mathrm{t}_{1 / 2}=700$, enabling plans for its possible therapeutic utilization (15). Indeed, VLHL PAI-1 has successfully been used to shorten the total time of bleeding and total blood loss in mice $(22,23)$.

On a cellular level PAI-1 inhibits the consecutive stages of cell migration both by direct blockage of the proteolytic activity of urokinase and by induction of the internalization of the uPA-uPAR complex and suppression of its chemokine-like and adhesion-like effect (19).

In molecular interactions PAI-1 inserts arginine 369 into the specificity pocket of UPA or IPA, preventing the reaction of activators with plasminogen. Similar blocking can be accomplished by small molecules or polypeptides. Thus, there is a search for such small molecule inhibitors, which can block PA activity as the natural inhibitor, PAI-1 does (24-26). It seems feasible to seek these molecules among dietary components that pass through the oral cavity.

\section{Plasminogen activation system in periodontal disease}

PAs have been found in the oral mucosa (27), saliva (28) and gingival crevicular fluid (GCF) (29) in 100-fold greater concentration than in plasma. The activity of PAs was observed at the site of desquamation of the junctional epithelium in healthy

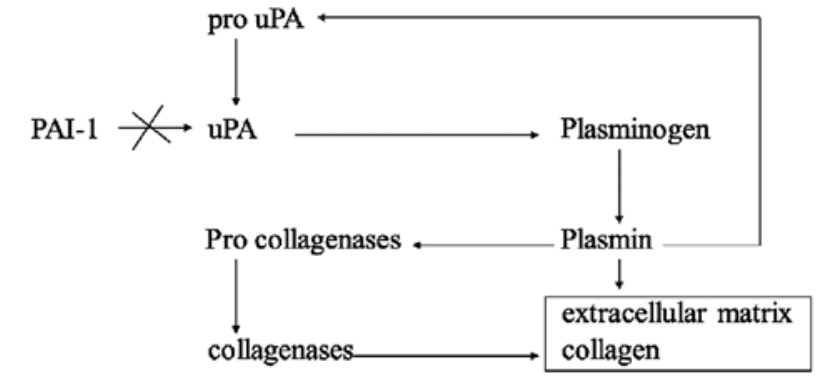

Figure 1. Pro-urokinase plasminogen activator (uPA) and tissue-type plasminogen activator (tPA) are synthesized and activated by catalytic amounts of plasmin. Both activators cleave plasminogen to active plasmin, that degrades proteins of the extracellular matrix or activates other proteases.

tissue and post-treatment, in which there were residual inflammatory cells. This site-specific pattern is greatly altered during periodontal disease (29), as described below.

\section{Wound healing}

Wound healing in periodontal tissue is a complex interrelationship between epithelial and connective tissue, affected also by contact with saliva and crevicular fluid. Wound healing in the periodontal connective tissue as a new attachment or re-attachment requires different types of connective tissue matrices, but initially it is similar to the other types of connective tissue and proceeds with provisional matrix formation (30), of which fibrin is a major constituent (31).

It has been well documented that during the early phase of wound healing (1-3 days), PAI-1 and PAI-2 are strongly associated with infiltrating inflammatory cells around the fibrin clot in the gingival sulcus, accompanied by the presence of uPA and the absence of tPA in healing wounds $(32,33)$. During the next phase (granulation tissue formation) of wound healing, uPA, PAI-1 and PAI-2 are observed in monocytes, macrophages and fibroblasts $(32,33)$. PAI-1 has been shown to be an important factor in inflammation-induced macrophage migration, which is essential for defense functions (34). uPA additionally has been observed in endothelial cells of newly formed blood vessels (32). It has been suggested that plasminogen activation plays a role in the migration of keratinocytes (35) and fibroblasts $(33,36)$, as well as tissue remodeling in the wound healing (32) of periodontal tissue. The role of PAS in the regulation of fibronectin proteolysis and fibroblast apoptosis and a potential role of transforming growth factor- $\beta 1$ (TGF- $\beta 1$ )/PAI- 1 in promoting (myo)fibroblast survival in chronic fibrotic disorders has also been pointed out (37). Fibronectin, one of the extracellular matrix components, is a substrate for PA (38). Additionally, it can be the substrate for multiple host and bacterial proteinases found in inflamed periodontal sites. The smaller fragments of fibronectin ( 30 and $45 \mathrm{kDa}$ ) are the most potent inflammatory inducers, as they have been shown to dose-dependently increase the secretion of tumor necrosis factor- $\alpha$ (TNF- $\alpha$ ), and interleukin (IL)-1 $\beta$ and IL- 8 by human macrophages (39).

Plasmin also plays a role in bone formation through the activation of TGF- $\beta$ and the release of insulin-like growth factor from the bone matrix, which stimulate osteoblast proliferation and activity (40). Osteoblasts express both PAs, PAI-1 and a cellular receptor for uPA (41). Due to the influence on 
A

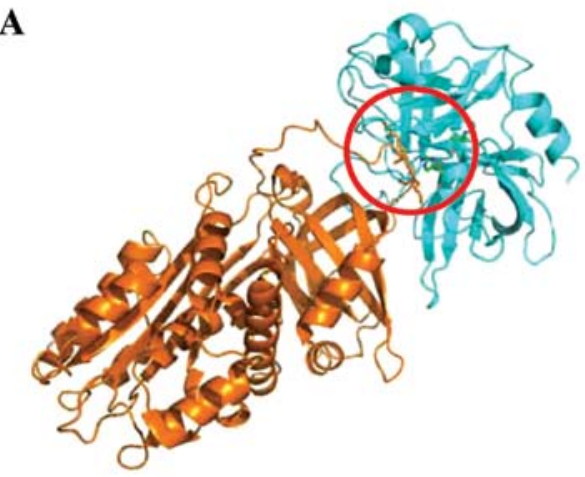

B

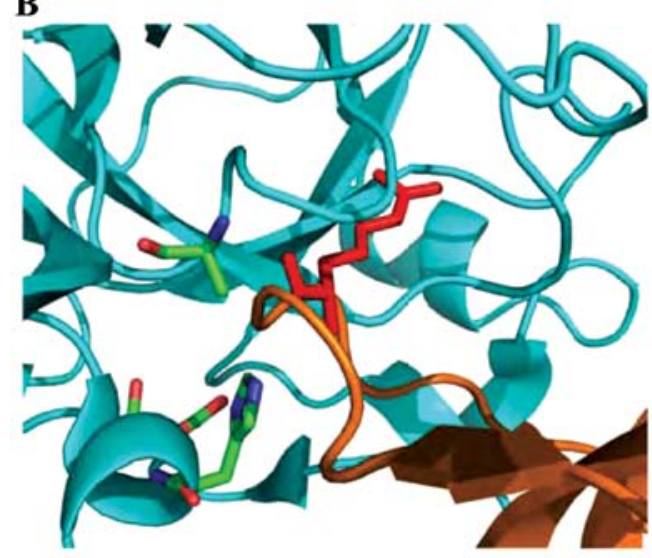

C

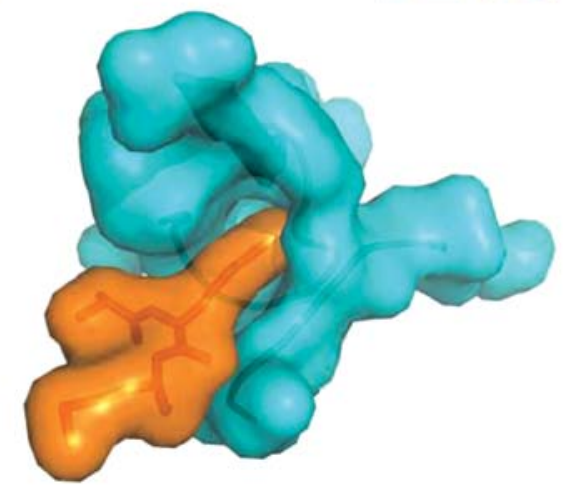

Figure 2. Ribbon model of: (A) active form of plasminogen activator inhibitor-1 (PAI-1) in orange in complex with urokinase plasminogen activator (uPA) in light blue; red circle shows reactive center loop of PAI-1 complexed with uPA; (B) enlarged active site of uPA in complex with PAI-1, active site amino acids (His57, Asp102 and Ser195) shown as stick model colored as follows: green-carbon, blue-nitrogen, red-oxygen; arginine (Arg269) inserted into specificity pocket of uPA is shown as a stick model in red (for clarity hydrogens are omitted). (C) Specificity pocket of uPA and P2, P1, P1' amino acids (red sticks) from the reactive center loop of PAI-1 are shown as surface models (light blue and orange, respectively). The specificity pocket is where the vast majority of uPA inhibitors are bound (16,75-78).

the degradation of non-collagenous components of the bone matrix, plasmin may be important in the resorption phase of bone regeneration (42).

\section{Inflammation}

From the molecular and cell biology point of view, the periodontium can be considered an organ system composed of two hard tissue (bone and cementum) and two soft tissue (periodontal ligaments and gingiva) components, of which each has a unique tissue architecture and biochemical compo- sition $(43,44)$. The degradation of the extracellular matrix of these components can occur through a number of different pathways, such as MMP activation, reactive oxygen species, cytokine release, prostaglandin synthesis and cell activation, and can modify host responses to inflammatory stimuli, contributing to the imbalance between biofilm and host immune response.

GCF contains both types of PAs, as well as their inhibitors (45); tPA and PAI-2 have been found in GCF in very high concentrations and seem to be predominant components in the gingival sulcus environment (46). Gingivitis (47) and periodontitis (48) have always associated with high levels of those enzymes. The treatment of periodontitis leads to a significant decrease in PAI-2, but not tPA levels (45). In a previous study, differences were observed in TPA/PAI- 2 ratios between deteriorating and stable sites in patients treated for periodontitis (49).

Biopsies from gingival tissues of different conditions prepared for in situ hybridization and immunochemistry have revealed that in clinically healthy gingiva, both tPA mRNA and antigen were expressed in a thin outer layer of sulcular and junctional epithelium, and similarly but more extensively in chronic gingivitis or early periodontitis. As previously demonstrated, there were no signals or staining for tPA in connective tissue, occasionally in connection with vessels. PAI- 2 mRNA was detected in the same sites and intensity as tPA, but also extended toward the connective tissue $(50,51)$.

A previous study demonstrated that there was a significant increase in PA activity and tPA antigen in samples from inflamed gingiva compared to healthy gingiva and with decreasing severity of periodontitis in canines. PAI-1 antigen measured by ELISA was not detected in the collected samples. The authors concluded that PA activity and IPA antigen levels may be used to evaluate the progression of periodontal disease (52).

On the other hand, the progression of periodontitis has been associated with the increase in PAI-1 levels in plasma (53). As PAI-1 is a protein involved in acute-phase response (54) of which periodontitis is one of the components, and hemostatic factor associated with cardiovascular disease development, it has been suggested that periodontitis as a chronic infection may lead to the formation of atherosclerotic lesions (55) and an increased risk of cardiovascular disease (53).

Furthermore, the incubation of periodontal ligament fibroblasts and gingival fibroblasts with platelet-derived growth factor-BB isoform has been shown to increase uPA and PAI-1, but not tPA and PAI-2 levels (56).

\section{Microbial infection}

Proteases released by periopathogens are responsible for collagen, fibronectin and laminin degradation in periodontal tissues (57). Gingival fibroblasts can be stimulated by a protease of Bacteroides (porphyromonas) gingivalis (58), Porphyromonas endodontalis (59), lipopolysaccharide (60) and IL-1 (61), to secrete collagenase and PA enzymes (59), but not directly by chemokines (62). In addition, in association with host MMPs, they play an important role in the progression of periodontal disease (63). Bacterial products, such a streptokinase and staphylokinase can activate plasminogen into plasmin by a non-proteolytic mechanism (64). Some bacterial pathogens can induce localised proteolysis, important in tissue 
damage and penetration through natural host barriers. During PA production, it is possible to capture the active plasmin on the cell surface and bind human plasminogen, which may be activated into plasmin by host PAs $(65,66)$. Plasminogen bound to bacteria may promote host tissue destruction and invasion even by non-proteolytic bacteria (67). In addition, this mechanism allows bacterial pathogens to migrate from periodontal tissue, through the bloodstream to the various host organs (68).

\section{Plasminogen activation system deficiencies}

Congenital PAI-1 deficiency is a rare autosomal recessive disorder, characterized clinically by excessive bleeding even with minor cuts or trauma (69). Individuals with PAI-1 deficiency bleed as a result of a hyperfibrinolytic hemorrhage. The primary hemostasis is normal (e.g., a normal thrombus is formed), but it is quickly lysed as there is no inhibitor to moderate tPA plasmin activation (70). Spontaneous bleeding is rarely observed, but moderate hemorrhaging of the gums, knees, elbows and nose can be triggered by very little trauma. Moderate PAI-1 deficiency is manifested with a lifelong bleeding tendency, but severe deficiency can be life-threatening (71). Only two types of mutations have been reported to be associated with PAI-1 deficiency. One is the frame-shift mutation in exon 4 of the PAI-1 gene, resulting in a truncated non-functional protein. The other concerns single nucleotide polymorphisms (SNPs) of Ala15Thr and Val17Ile mutations in the signal peptide. These cause reduced PAI-1 secretion, leading to the deficiency at a time and place where it is needed (72). PAI-1 deficiency can be treated with systemic or topical applications of PAI-1 with an extended half-life (73) or with a 5- to 7-day course of oral tranexamic acid or $\varepsilon$-aminocaproic acid (69).

In their study, El Darouti et al (74) reported a case of ligneous conjunctivitis and ligneous periodontitis in association with plasminogen deficiency, based on the decreased serum activity of this enzyme. The predominant plasminogen gene mutation in patients suffering from the disease is the point mutation, Lys19Glu. Topical plasminogen from fresh or frozen plasma in the form of ointments holds some promise as a treatment for the disease. However, impaired extracellular fibrinolysis and chronic mucosal pseudomembranous lesions due to subepithelial fibrin deposition and inflammation most likely will be treated with gene therapy. To our knowledge, there are no studies available on UPA and tPA deficiencies in the pathology of the oral cavity.

\section{Inhibitors}

The associations between diet and periodontal disease seem to be very interesting in terms of the utilization of nutrients which are natural inhibitors of PAS. PAI-1 is produced by adipocytes and stromal cells surrounding the adipocytes and its level increases, particularly in the abdominal area adipose tissue (79). There are some studies suggesting an association between periodontal disease and obesity (80), particularly in the case of visceral fat, which leads to hepatic steatosis (81).

Recent studies have revealed better periodontal conditions in vegetarians (82), who consume a large amount of soy food. They manifest in the improvement of such clinical parameters, as lower probing pocket depth (PPD), bleeding on probing (BOP) and periodontal screening index (PSI) The highest two quintiles of total soya intake have been associated with a $32-35 \%$ reduction in the odds of developing periodontal disease (83). Soybeans are a unique source of isoflavones (genistein, daidzein) which can inhibit epidermal growth factor (EGF)-stimulated urokinase production (84). Similar daily consumption of other polyphenols, such as catechins in green tea has shown to have a positive impact on periodontal clinical parameters (85). One of the suggested mechanisms is the activation of kinase-signaling cascades that suppress PAI-1 expression (86). Epigallocatechin-3-gallate (EGCG), a major green tea catechin, has been shown to downregulate TNF and IL-6 expression, leading to a decrease in osteoclast number and activity in rats (87). EGCG also inhibits CC chemokine ligand 11 (CCL11) production in human gingival fibroblasts, related to Th2 cell migration (88).

The other well documented component of food with beneficial properties is a popular spice, curcumin. It may have therapeutic potential in periodontal disease (89), possibly through the upregulation of uPA, which is instrumental in promoting fibrynolysis and cell migration during wound healing (90).

\section{Conclusion}

Periodontal disease is a chronic, opportunistic infection, caused by an imbalance between biofilm-forming bacteria and the host immune response. Even in clinically healthy gingiva nutrophiles and lymphocytes are still present and endothelial cells reactions are stimulated by adhesins. Acute inflammation is always associated with bleeding, redness and swelling of the gingival tissue and with an increased leakage of crevicular fluid. Endogenous mediators of inflammation, such as PAS, are crucial for this phase of inflammation. However, the components of PAS are also detected in all periodontal cells in the chronic and healing phase of inflammation, which may indicate their complex influence on the periodontium. The deficiency of plasmin or PAI-1 causes spontaneous bleeding and the destruction of periodontal supporting tissue, and can be treated with topic or systemic supplementation. On the other hand, natural inhibitors of PAI-1 can improve the clinical periodontal tissue condition. Knowledge of the complex interactions of proteins in disease is derived mostly from animal models. Proteins of different organisms frequently differ from each other in a surprising manner. For example, mouse uPA and human uPA are very similar to each other, while rat uPA differs significantly from that of mice and humans. Thus, it is important to remember that conclusions derived from animal studies must take into consideration the limitations of the selected animal model and its applicability to humans.

\section{Acknowledgements}

This study was supported in part by grants from Frank Stranahan Endowed Chair and Children Miracle Network to J.J.

\section{References}

1. Conese $\mathrm{M}$ and Blasi F: The urokinase/urokinase-receptor system and cancer invasion. Baillieres Clin Haematol 8: 365-389, 1995. 
2. Rakic JM, Maillard C, Jost M, et al: Role of plasminogen activator-plasmin system in tumor angiogenesis. Cell Mol Life Sci 60: 463-473, 2003.

3. Slot O, Brünner N, Locht H, Oxholm P and Stephens RW: Soluble urokinase plasminogen activator receptor in plasma of patients with inflammatory rheumatic disorders: increased concentrations in rheumatoid arthritis. Ann Rheum Dis 58: 488-492, 1999.

4. Stoppelli MP, Tacchetti C, Cubellis MV, et al: Autocrine saturation of pro-urokinase receptors on human A431 cells. Cell 45 675-684, 1986.

5. Lijnen HR, Maquoi E, Hansen LB, Van Hoef B, Frederix L and Collen D: Matrix metalloproteinase inhibition impairs adipose tissue development in mice. Arterioscler Thromb Vasc Biol 22 374-379, 2002.

6. Andreasen PA, Egelund R and Petersen HH: The plasminogen activation system in tumor growth, invasion, and metastasis. Cell Mol Life Sci 57: 25-40, 2000.

7. Andreasen PA, Kjøller L, Christensen L and Duffy MJ: The urokinase-type plasminogen activator system in cancer metastasis: a review. Int J Cancer 72: 1-22, 1997.

8. Blasi F: uPA, uPAR, PAI-1: key intersection of proteolytic, adhesive and chemotactic highways? Immunol Today 18 : 415-417, 1997.

9. Sitrin RG, Todd RF III, Albrecht E and Gyetko MR: The urokinase receptor (CD87) facilitates CD11b/CD18-mediated adhesion of human monocytes. J Clin Invest 97: 1942-1951, 1996.

10. Stefansson S and Lawrence DA: The serpin PAI-1 inhibits cell migration by blocking integrin alpha $\mathrm{V}$ beta 3 binding to vitronectin. Nature 383: 441-443, 1996.

11. Ginsburg D, Zeheb R, Yang AY, et al: cDNA cloning of human plasminogen activator-inhibitor from endothelial cells. J Clin Invest 78: 1673-1680, 1986.

12. Chorostowska-Wynimko J, Skrzypczak-Jankun E and Jankun J: Plasminogen activator inhibitor type-1: Its structure, biological activity and role in tumorigenesis (Review). Int J Mol Med 13 759-766, 2004

13. Stefansson S, McMahon GA, Petitclerc E and Lawrence DA: Plasminogen activator inhibitor-1 in tumor growth, angiogenesis and vascular remodeling. Curr Pharm Des 9: 1545-1564, 2003.

14. Yamamoto K and Saito H: A pathological role of increased expression of plasminogen activator inhibitor-1 in human or animal disorders. Int J Hematol 68: 371-385, 1998.

15. Chorostowska-Wynimko J, Swiercz R, Skrzypczak-Jankun E, Wojtowicz A, Selman SH and Jankun J: A novel form of the plasminogen activator inhibitor created by cysteine mutations extends its half-life: relevance to cancer and angiogenesis. Mol Cancer Ther 2: 19-28, 2003.

16. Jankun J, Yang J, Zheng H, Han FQ, Al-Senaidy A and Skrzypczak-Jankun E: Remarkable extension of PAI-1 half-life surprisingly brings no changes to its structure. Int J Mol Med 29: 61-64, 2012.

17. Berkenpas MB, Lawrence DA and Ginsburg D: Molecular evolution of plasminogen activator inhibitor-1 functional stability. EMBO J 14: 2969-2977, 1995.

18. Tucker HM, Mottonen J, Goldsmith EJ and Gerard RD Engineering of plasminogen activator inhibitor-1 to reduce the rate of latency transition. Nat Struct Biol 2: 442-445, 1995.

19. Dano K, Andreasen PA, Grondahl-Hansen J, Kristensen P, Nielsen LS and Skriver L: Plasminogen activators, tissue degradation, and cancer. Adv Cancer Res 44: 139-266, 1985.

20. Swiercz R, Keck RW, Skrzypczak-Jankun E, Selman SH and Jankun J: Recombinant PAI-1 inhibits angiogenesis and reduces size of $\mathrm{LNCaP}$ prostate cancer xenografts in SCID mice. Oncol Rep 8: 463-470, 2001.

21. Swiercz R, Skrzypczak-Jankun E, Merrell MM, Selman SH and Jankun J: Angiostatic activity of synthetic inhibitors of urokinase type plasminogen activator. Oncol Rep 6: 523-526, 1999.

22. Jankun J, Aleem AM, Selman SH, et al: Highly stable plasminogen activator inhibitor type one (VLHL PAI-1) protects fibrin clots from tissue plasminogen activator-mediated fibrinolysis. Int J Mol Med 20: 683-687, 2007.

23. Jankun J, Aleem AM, Struniawski R, Lysiak-Szydlowska W, Selman SH and Skrzypczak-Jankun E: Accelerated thrombus lysis in the blood of plasminogen activator inhibitor deficient mice is inhibited by PAI-1 with a very long half-life. Pharmacol Rep 61: 673-680, 2009.

24. Klinghofer V, Stewart K, McGonigal T, et al: Species specificity of amidine-based urokinase inhibitors. Biochemistry 40: 9125-9131, 2001
25. Zeslawska E, Jacob U, Schweinitz A, Coombs G, Bode W and Madison E: Crystals of urokinase type plasminogen activator complexes reveal the binding mode of peptidomimetic inhibitors. J Mol Biol 328: 109-118, 2003.

26. Zhao G, Yuan C, Wind T, Huang Z, Andreasen PA and Huang M: Structural basis of specificity of a peptidyl urokinase inhibitor, upain-1. J Struct Biol 160: 1-10, 2007.

27. Birn H and Fejerskov O: Fibrynolotic activity of human oral epithelial cells: A preliminary report. Scand J Dent Res 79: 381-386, 1971.

28. Moody GH: The source of plasminogen activator in human saliva. Archs Oral Biol 27: 33-37, 1982.

29. Schmid J, Cohen RL and Chambers DA: Plasminogen activator in human periodontal health and disease. Arch Oral Biol 36: 245-250, 1991.

30. Bartold PM, Walsh LJ and Narayanan AS: Molecular and cell biology of the gingiva. Periodontol 2000 24: 28-55, 2000.

31. Schafer BM, Maier K, Eickhoff U, Todd RF and Kramer MD Plasminogen activation in healing human wounds. Am J Pathol 144: 1269-1280, 1994.

32. Xiao Y, Li H, Bunn C and Bartold PM: The expression of plasminogen activator system in a rat model of periodontal wound healing. J Periodontol 72: 849-857, 2001.

33. Schaefer BM, Maier K, Eickhoff U, Bechtel M and Kramer MD: alpha 2-Antiplasmin and plasminogen activator inhibitors in healing human skin wounds. Arch Dermatol Res 288: 122-128, 1996.

34. Thapa B, Kim YH, Kwon HJ and Kim DS: Novel regulatory mechanism and functional implication of plasminogen activator inhibitor-1 (PAI-1) expression in CpG-ODN-stimulated macrophages. Mol Immunol 49: 572-581, 2012.

35. Morimoto K, Mishima H, Nishida T and Otori T: Role of urokinase type plasminogen activator (u-PA) in corneal epithelial migration. Thromb Haemost 69: 387-391, 1993

36. Abiko Y, Arai J, Matsuzawa K, Inoue T, Shimono M and Kaku T: Human gingival fibroblast migration promoted by plateletderived growth factor on titanium is correlated with release of urokinase type plasminogen activator. Bull Tokyo Dent Coll 37: 113-118, 1996.

37. Horowitz JC, Rogers DS, Simon RH, Sisson TH and Thannickal VJ: Plasminogen activation induced pericellular fibronectin proteolysis promotes fibroblast apoptosis. Am J Respir Cell Mol Biol 38: 78-87, 2008.

38. Quigley JP, Gold LI, Schwimmer R and Sullivan LM: Limited cleavage of cellular fibronectin by plasminogen activator purified from transformed cells. Proc Natl Acad Sci USA 84: 2776-2780, 1987.

39. Feghali K and Grenier D: Priming effect of fibronectin fragments on the macrophage inflammatory response: potential contribution to periodontitis. Inflammation 35: 1696-1705, 2012.

40. Yee JA, Yan L, Dominguez JC, Allan EH and Martin TJ: Plasminogen-dependent activation of latent transforming growth factor beta (TGF beta) by growing cultures of osteoblast-like cells. J Cell Physiol 157: 528-534, 1993.

41. Allan EH and Martin TJ: The plasminogen activator inhibitor system in bone cell function. Clin Orthop Relat Res 313: 54-63, 1995.

42. Daci E, Everts V, Torrekens S, et al: Increased bone formation in mice lacking plasminogen activators. J Bone Miner Res 18: 1167-1176, 2003

43. Bartold PM: Periodontal tissues in health and disease: introduction. Periodontol 2000 40: 7-10, 2006.

44. Bartold PM and Narayanan AS: Molecular and cell biology of healthy and diseased periodontal tissues. Periodontol 2000 40: 29-49, 2006.

45. Kinnby B, Lecander I, Martinsson G and Astedt BK: Tissue plasminogen activator and placental plasminogen activator inhibitor in human gingival fluid. Fibrinolysis 5: 239-242, 1991.

46. Kinnby B, Matsson L and Lecander I: The plasminogen-activating system in gingival fluid from adults. An intra-individual study before and after treatment of gingivitis. Scand J Dent Res 102: 334-341, 1994.

47. Olofsson A, Lindberg P, Lanke J, Matsson L and Kinnby B Relationship between fibrinolytic activity and gingival inflammatory reaction in young individuals. J Periodontal Res 38 : 104-108, 2003.

48. Yin X, Bunn CL and Bartold PM: Detection of tissue plasminogen activator (t-PA) and plasminogen activator inhibitor 2 (PAI-2) in gingival crevicular fluid from healthy, gingivitis and periodontitis patients. J Clin Periodontol 27: 149-156, 2000. 
49. Olofsson A, Matsson L and Kinnby B: Plasminogen activating capacity in gingival fluid from deteriorating and stable periodontal pockets. J Periodontal Res 37: 60-65, 2002.

50. Kinnby B, Lindberg P, Lecander I and Matsson L: Localisation of plasminogen activator inhibitors in human gingival tissue demonstrated by immunochemistry and in situ hybridization. Arch Oral Biol 44: 1027-1034, 1999.

51. Lindberg P, Kinnby B, Lecander I, Lang NP and Matsson L: Increasing expression of tissue plasminogen activator and plasminogen activator inhibitor type 2 in dog gingival tissues with progressive inflammation. Arch Oral Biol 46: 23-31, 2001.

52. Papadimitriou S, Tsantarliotou M, Makris G, et al: A clinical study of plasminogen activator activity in gingival tissue in dogs with gingivitis and periodontitis. Res Vet Sci 80: 189-193, 2006.

53. Bizzarro S, van der Velden U, ten Heggeler JM, et al: Periodontitis is characterized by elevated PAI-1 activity. J Clin Periodontol 34 574-580, 2007.

54. De Taeye B, Smith LH and Vaughan DE: Plasminogen activator inhibitor-1: a common denominator in obesity, diabetes and cardiovascular disease. Curr Opin Pharmacol 5: 149-154, 2005.

55. Munford RS: Statins and the acute-phase response. N Engl J Med 344: 2016-2018, 2001.

56. Agis H, Bauer M, Knebl G, Watzek G and Gruber R: Effects of platelet-derived growth factor isoforms on plasminogen activation by periodontal ligament and gingival fibroblasts. J Periodontal Res 43: 334-342, 2008.

57. Haffajee AD and Socransky SS: Microbial etiological agents of destructive periodontal diseases. Periodontol 2000 5: 78-111, 1994.

58. Uitto VJ, Larjava H, Heino $\mathrm{J}$ and Sorsa T: A protease of Bacteroides gingivalis degrades cell surface and matrix glycoproteins of cultured gingival fibroblasts and induces secretion of collagenase and plasminogen activator. Infect Immun 57: 213-218, 1989

59. Oikawa T, Ogura N, Akiba M, Abiko Y, Takiguchi $\mathrm{H}$ and Izumi H: Stimulation of plasmin activity in cultured human fibroblast cells by Porphyromonas endodontalis. Int J Biochem 25: 1227-1231, 1993

60. Ogura N, Shibata Y, Matsuda U, et al: Effect of Campylobacter rectus LPS on plasminogen activator-plasmin system in human gingival fibroblast cells. J Periodontal Res 30: 132-140, 1995.

61. Mochan E, Armor L and Sporer R: Interleukin 1 stimulation of plasminogen activator production in cultured gingival fibroblasts. J Periodontal Res 23: 28-32, 1988.

62. Sarajlic J, Agis H, Kandler B, Watzek G and Gruber R: Plasminogen activation by fibroblasts from periodontal ligament and gingiva is not directly affected by chemokines in vitro. Arch Oral Biol 52: 663-668, 2007.

63. Birkedal-Hansen H: Role of matrix metalloproteinases in human periodontal diseases. J Periodontol 64: 474-484, 1993.

64. Johnston KH: Solid and fluid phase assays for bacterial plasminogen activators. J Microbiol Methods 18: 267-274, 1993.

65. Lottenberg R, Minning-Wenz D and Boyle MD: Capturing host plasmin(ogen): a common mechanism for invasive pathogens? Trends Microbiol 2: 20-24, 1994

66. Pantzar M, Ljungh A and Wadstrom T: Plasminogen binding and activation at the surface of Helicobacter pylori CCUG 17874. Infect Immun 66: 4976-4980, 1998.

67. Darenfed H, Grenier D and Mayrand D: Acquisition of plasmin activity by Fusobacterium nucleatum subsp. nucleatum and potential contribution to tissue destruction during periodontitis. Infect Immun 67: 6439-6444, 1999.

68. Bennett KW and Eley A: Fusobacteria: new taxonomy and related diseases. J Med Microbiol 39: 246-254, 1993.

69. Jankun J and Skrzypczak-Jankun E: Yin and yang of the plasminogen activator inhibitor. Pol Arch Med Wewn 119: 410-417, 2009.

70. Largent V, Deneys V, Brichard B, Chantrain C and Vermylen C: Bleeding diathesis in a child with normal screening tests: think about fibrinolysis. Eur J Pediatr 164: 587-588, 2005.
71. Mehta R and Shapiro AD: Plasminogen activator inhibitor type 1 deficiency. Haemophilia 14: 1255-1260, 2008.

72. Jankun J and Skrzypczak-Jankun E: Bleeding diathesis is associated with an A15T heterozygous mutation in exon 2 of the plasminogen activator inhibitor type 1. Exp Ther Med 1: 575-577, 2010.

73. Jankun J, Keck R, Selman SH and Skrzypczak-Jankun E: Systemic or topical application of plasminogen activator inhibitor with extended half-life (VLHL PAI-1) reduces bleeding time and total blood loss. Int J Mol Med 26: 501-504, 2010.

74. El-Darouti M, Zayed AA, El-Kamah GY and Mostafa MI: Ligneous conjunctivitis with oral mucous membrane involvement and decreased plasminogen level. Pediatr Dermatol 26: 448-451, 2009.

75. Lin Z, Jiang L, Yuan C, et al: Structural basis for recognition of urokinase-type plasminogen activator by plasminogen activator inhibitor-1. J Biol Chem 286: 7027-7032, 2011.

76. Zeslawska E, Schweinitz A, Karcher A, et al: Crystals of the urokinase type plasminogen activator variant beta(c)-uPAin complex with small molecule inhibitors open the way towards structure-based drug design. J Mol Biol 301: 465-475, 2000.

77. Brown NJ: Therapeutic potential of plasminogen activator inhibitor-1 inhibitors. Ther Adv Cardiovasc Dis 4: 315-324, 2010.

78. Xue Y, Björquist P, Inghardt T, et al: Interfering with the inhibitory mechanism of serpins: crystal structure of a complex formed between cleaved plasminogen activator inhibitor type 1 and a reactive-centre loop peptide. Structure 6: 627-636, 1998.

79. Mavri A, Alessi MC, Bastelica D, Geel-Georgelin O, et al: Subcutaneous abdominal, but not femoral fat expression of plasminogen activator inhibitor-1 (PAI-1) is related to plasma PAI-1 levels and insulin resistance and decreases after weight loss. Diabetologia 44: 2025-2031, 2001.

80. Ritchie CS: Obesity and periodontal disease. Periodontol 2000 44: 154-163, 2007.

81. Saito T, Shimazaki Y, Koga T, et al: Relationship between periodontitis and hepatic condition in Japanese women. J Int Acad Periodontol 8: 89-95, 2006.

82. Staufenbiel I, Weinspach K, Förster G, et al: Periodontal condition in vegetarians: a clinical study. Eur J Clin Nutr 67: 836-840, 2013 .

83. Tanaka K, Sasaki S, Murakami K, et al: Relationsip between soy and isoflavone intake and periodontal disesae: the freshmen in dietetic Courses Study II. BMC Public Health 8: 39-46, 2008.

84. Smith PC, Santibañez JF, Morales JP and Martinez J: Epidermal growth factor stimulates urokinase-type plasminogen activator expression in human gingival fibroblasts. Possible modulation by genistein and curcumin. J Periodont Res 39: 380-387, 2004.

85. Kushiyama M, Shimazaki Y, Murakami M and Yamashita Y: Relationship between intake of green tea and periodontal disease. J Periodontol 80: 372-377, 2009.

86. Pasten C, Olave NC, Zhou L, et al: Polyphenols downregulate PAI-1 gene expression in cultured human coronary artery endothelial cells: molecular contributor to cardiovascular protection. Thromb Res 121: 59-65, 2007.

87. Cho AR, Kim JH, Lee DE, et al: The effect of orally administrated epigallocatechin-3-gallate on ligature-induced periodontitis in rats. J Periodontol 48: 781-789, 2013.

88. Hosokawa Y, Hosokawa I, Shindo S, et al: (-)-Epigallocatechin3-gallate inhibits $\mathrm{CC}$ chemokine ligand 11 production in human gingival fibroblasts. Cell Physiol Biochem 31: 960-967, 2013.

89. Guimarães MR, Coimbra LS, de Aquino SG, et al: Potent antiinflammatory effects of systemically administrated curcumin modulate periodontal disease in vivo. J Periodontal Res 46: 269-279, 2011.

90. Madhyastha R, Madhyastha $\mathrm{H}$, Nakajima $\mathrm{S}$, et al: Curcumin facilitates fibrynolysis and cellular migration during wound healing by modulation urokinase plasminogen activator expression. Pathophysiol Haemost Thromb 37: 59-66, 2010. 